\title{
Boron-Containing Phthalocyanines and Porphyrazines
}

\author{
Igor B. Sivaev, ${ }^{\mathrm{a} @ ~ V l a d i m i r ~ I . ~ B r e g a d z e, ~}{ }^{\mathrm{a}}$ Ahmet Gül, $^{\mathrm{b}}$ and Andrey F. Mironov ${ }^{\mathrm{c}}$ \\ Dedicated to $\mathrm{A}$. Yu. Tsivadze on the occasion of his $70^{\text {th }}$ birthday \\ ${ }^{a}$ A.N. Nesmeyanov Institute of Organoelement Compounds, Russian Academy of Sciences, 119991 Moscow, Russia \\ ${ }^{\mathrm{b}}$ Technical University of Istanbul, Department of Chemistry, Maslak, TR34469 Istanbul, Turkey \\ ${ }^{c}$ M.V. Lomonosov Moscow State University of Fine Chemical Technologies, 119571 Moscow, Russia \\ ${ }^{\circledR}$ Corresponding authorE-mail: sivaev@ineos.ac.ru
}

The design and synthesis of boron-containing phthalocyanines and porphyrazines is reviewed. Some of the compounds obtained can be used as agents for photodynamic therapy (PDT) and boron neutron capture therapy of cancer (BNCT) as well as dual PDT/BNCT sensitizers.

Keywords: Phthalocyanines, porphyrazines, boron, polyhedral boranes, carboranes, metallacarboranes.

\section{Борсодержащие фталоцианины и порфиразины}

\author{
И. Б. Сиваев, ${ }^{\text {a }}$ В. И. Брегадзе, ${ }^{a}$ А. Гюль, ${ }^{\text {b }}$ А. Ф. Мироновс \\ Посвящается А. Ю. Циваgзе по случаю его 70-летнего юбилея

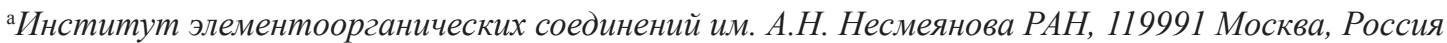

${ }^{\mathrm{b}}$ Technical University of Istanbul, Department of Chemistry, Maslak, TR34469 Istanbul, Turkey

${ }^{\mathrm{c}}$ Московский государственный университет тонких химических технологий им. М.В. Ломоносова, 119571 Москва, Россия

${ }^{\circledR}$ E-mail: sivaev@ineos.ac.ru
\end{abstract}

\begin{abstract}
Рассмотрень дизайн и синтез борсодержащих фталоцианинов и порфиразинов, которые могут найти использование в фотодинамической и бор-нейтронозахватной терапии рака.
\end{abstract}

Ключевые слова: Фталоцианины, порфиразины, бор, многогранные бораны, карбораны, металлокарбораны.

\section{Introduction}

Photodynamic therapy $(\mathrm{PDT})^{[1-7]}$ and boron neutron capture therapy $(\mathrm{BNCT})^{[8-12]}$ are selective treatment modalities for the local destruction of malignant tumors. The selectivity is based on the ability of a sensitizer molecule to preferentially accumulate in tumor tissue and upon its activation by the application of an external radiation source. In PDT photoactivation of sensitizer causes oxidative damage to a variety of cellular targets and subsequent tumor necrosis. In BNCT irradiation of boron compound with thermal neutron flux results in nuclear fission with localized emission of high linear energy transfer (LET) particles $\left({ }^{4} \mathrm{He}\right.$ and $\left.{ }^{7} \mathrm{Li}\right)$ having a penetration range of less than $10 \mu \mathrm{m}$ in biological tissues, which amounts to approximately one cell diameter.

Porphyrins and phthalocyanines employed for PDT demonstrate an improved selective accumulation in tumor tissues and retain there for a long period of time. This observation caused an interest in boron derivatives of porphyrins and phthalocyanines in order to find compounds which can be used as BNCT agents. Due to higher diversity of porphyrine compounds including many naturally occurring, the main attention was paid to synthesis of boron-containing porphyrins and this field has been reviewed several times since $2000 .^{[13-17]}$ 
This review describes the recent development of the chemistry of boron-containing phthalocyanines and porphyrazines excluding chemistry of boron subphthalocyanines ${ }^{[18]}$ which are intensively studied during the last two decades as precursors for asymmetrically substituted phthalocyanines ${ }^{[19-21]}$ and components of organic electronic materials. ${ }^{[22]}$

\section{Boron-Containing Phthalocyanines}

\section{Tri-and Tetra-coordinated Boron Compounds}

Since the discovery of phthalocyanines, many efforts are geared towards synthesis of their various derivatives, ${ }^{[23,24]}$ however only a very limited number of synthesis of boroncontaining phthalocyanines has been reported. In general there are two main approaches to synthesis of boronated phthalocyanines. The first one is based on modification of preformed macrocyclic core through the introduction of a boron moiety. The other one includes the template condensation of the corresponding boron-containing phthalonitriles. The synthetic scheme depends strongly on stability of boron fragment used. Low stability of majority of tri- and tetra-coordinated boron compounds under conditions of the template condensation precludes use of this approach.

Synthesis of the first phthalocyanine $\mathbf{1}$ containing tricoordinated boron atom at the periphery of the phthalocyanine backbone was reported only in 2009 using the Pd-catalyzed cross-coupling reaction of monoiodo tri-tert-butyl zinc phthalocyanine with bis(pinalcolato) diboron (Scheme 1). ${ }^{[25]}$ This Suzuki-phthalocyanine synthon was used for synthesis of various aryl phthalocyanines including covalently linked phthalocyanine-phthalocyanine heterodimers and phthalocyanine-phthalocyanine triads ${ }^{[25]}$ and phthalocyanine-peptide conjugates. ${ }^{[26]}$

Synthesis of the first phthalocyanine $\mathbf{2}$ containing substituents with tetracoordinated boron atoms by the complexation of zinc phthalocyanine bearing four salicy-

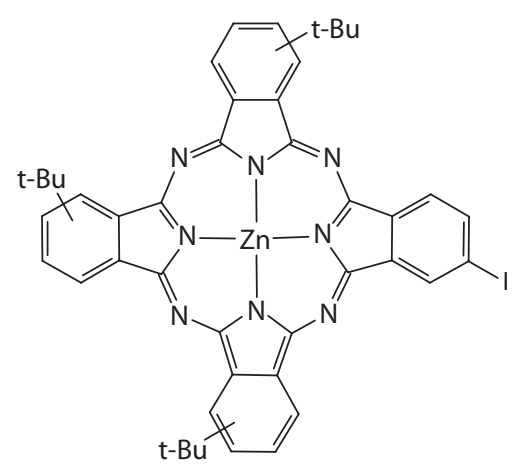<smiles>CC1(C)OB(B2OC(C)(C)C(C)(C)O2)OC1(C)C</smiles><smiles>CC(C)(C)CCC(C)(C)C</smiles>

1

Scheme 1.

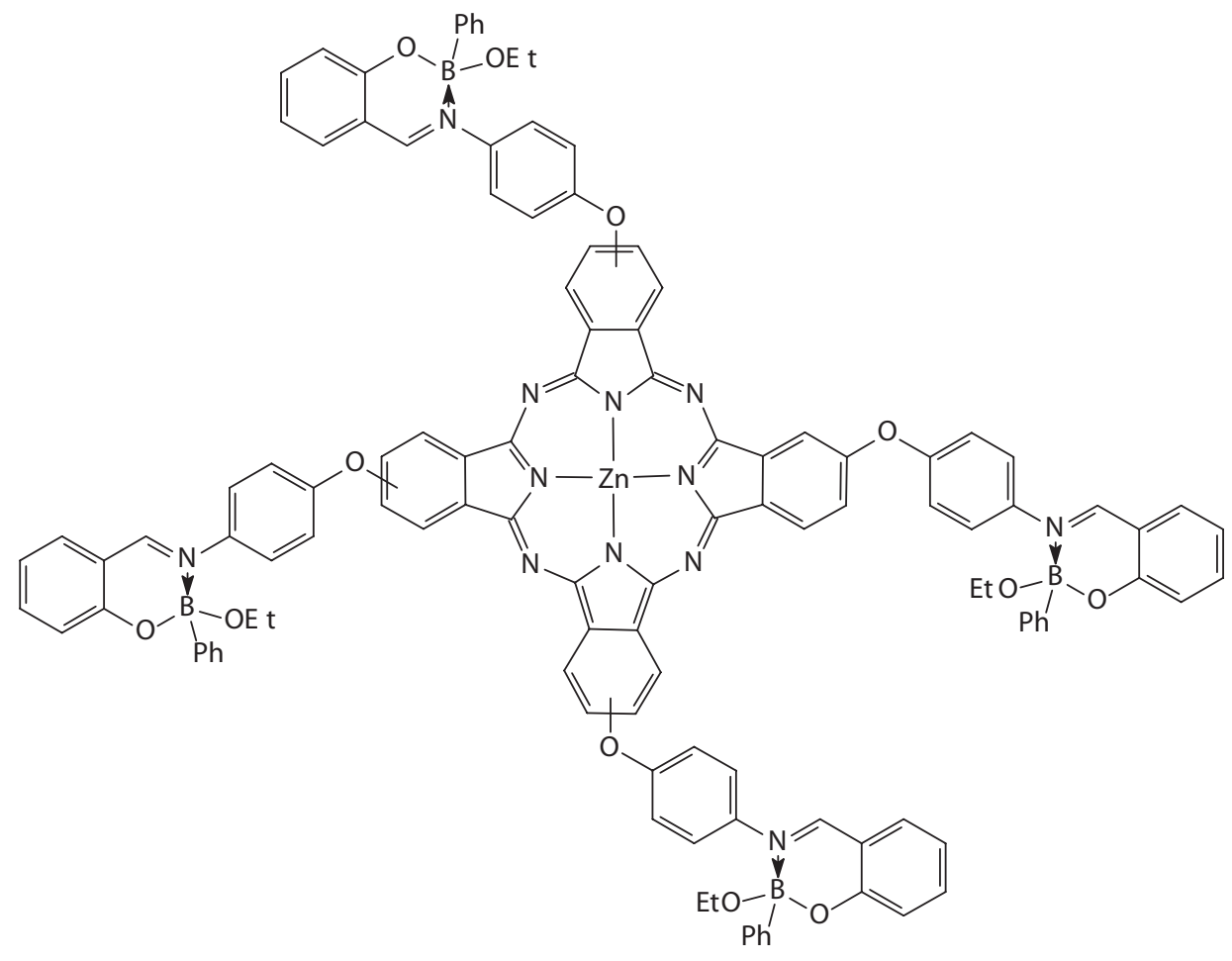


lideniminophenyloxy substituents with benzeneboronic acid has been reported very recently (Scheme 2). ${ }^{[27]}$

\section{Polyhedral Boron Compounds}

Much more work has been devoted to the synthesis of phthalocyanines containing polyhedral boron clusters (boranes, carboranes and metallacarboranes). The first report on compounds containing both carborane and phthalocyanine fragments was published in 1970 and dealt with thermal stability of polymers containing carborane and phthalocyanine groups. ${ }^{[28]}$ Later this area was covered by a few patents. ${ }^{[29-31]}$

Further development of this field is associated mainly with design and synthesis of new BNCT drugs. The first reported carborane-containing phthalocyanine for BNCT was prepared using the first approach by the reaction of 1-(4aminophenyl)-o-carborane with copper(II) phthalocyanine tetrasulfonylchloride followed by the hydrolysis of unreacted chlorosulfonic acid to sulfonic acid groups (Scheme 3). ${ }^{[32,33]}$ Unfortunately, no detailed information on synthesis and characterization of phthalocyanine $\mathbf{3}$ was reported.

High thermal and chemical stability of the carborane cage allows one to use both approaches to synthesis of carborane-containing phthalocyanines. A series of carborane-containing phthalocyanines was prepared by the tetramerization of boron-containing phthalocyanine precursors. The cobalt phthalocyanine 4 was prepared in $24 \%$ yield by the reaction of $\mathrm{CoCl}_{2}$ with 4-[4-(meta-carboran9-yl)phenoxy]phthalonitrile at $200{ }^{\circ} \mathrm{C}$ (Scheme 4). ${ }^{[34]}$ The zinc phthalocyanines 5 and $\mathbf{6}$ were prepared in 12 and $38 \%$ yields, respectively, by the reaction of zinc acetate with the corresponding phthalonitriles with at $220^{\circ} \mathrm{C}$. An alternative route based on acylation of zinc phthalocyanines bearing aniline and phenol terminal groups with the corresponding ortho-carboranyl acylchlorides gave 5 and $\mathbf{6}$ in 65 and $53 \%$ yields, respectively (Scheme 4$){ }^{[35]}$ In a similar way the reaction of zinc acetate with 3-[4-(ortho-carboran-1-yl) methylphenoxy]phthalonitrile at $210{ }^{\circ} \mathrm{C}$ gave the boronated zinc phthalocyanine 7 in $40 \%$ yield (Scheme 4). ${ }^{[36,37]}$

It was demonstrated that boronated phthalocyanine 7 can be efficiently accumulated by B16F1 melanotic melanoma cells in vitro and, upon red light irradiation, induced extensive cell mortality. The intravenous injection of 7 to C57BL/6 mice bearing a subcutaneously transplanted pigmented melanoma followed by irradiation with thermal neutrons $24 \mathrm{~h}$ after injection led to a 4 day delay in tumor growth as compared with control untreated mice. These

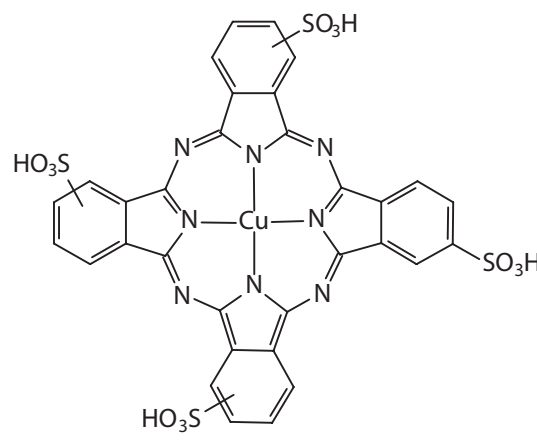

Scheme 3.
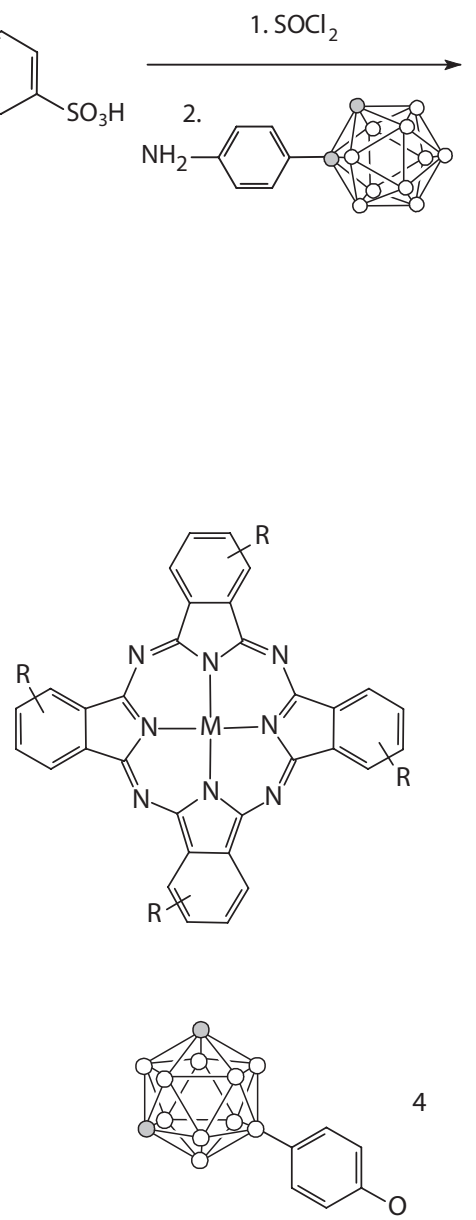

$\mathrm{M}=\mathrm{Co}$
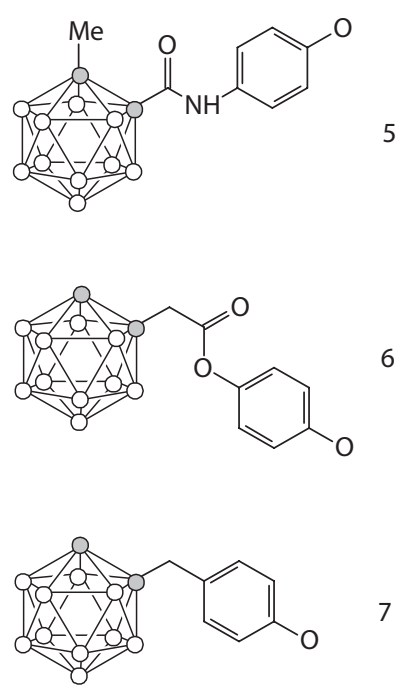

$M=Z n$

Scheme 4 . 
results open the possibility to use 7 both as a photosensitising and a radiosensitising agent for the treatment of tumors by the combined application of photodynamic therapy and boron neutron capture therapy. ${ }^{[37]}$

It should be noted that described above carboranecontaining phthalocyanines 4-7 are highly hydrophobic and insoluble in water. Water-soluble cobalt phthalocyanine 8 was prepared in $16 \%$ yield by the condensation of $\mathrm{CoCl}_{2}$ with dimethyl (3,4-dicyanophenyl)(ortho-carboran-1-ylmethyl)malonate at $200{ }^{\circ} \mathrm{C}$ followed by ester deprotection and cation exchange (Scheme 5). ${ }^{[38]}$ Water solubility of $\mathbf{8}$ is provided by the introduction of four carboxylic groups and their conversion to sodium salts.

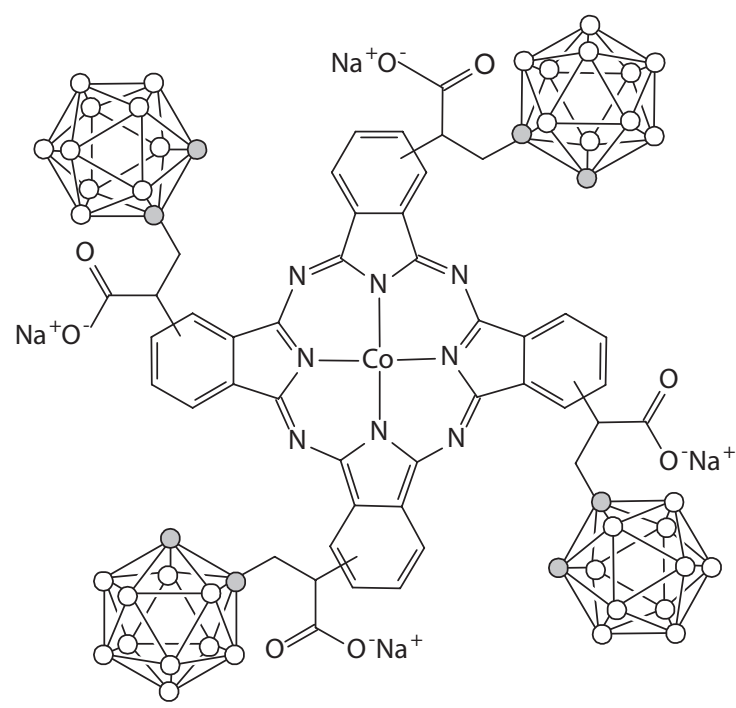

8
Another way to reach water-solubility of carborane derivatives is their transformation from the closo- to nido- form that can be performed in the presence of strong nucleophiles. ${ }^{[39]}$ Phthalocyanine 9 bearing eight nido-carborane groups was prepared by DBU-promoted cyclotetramerization of 4,5-dithiohexyl-(1-methyl-1,2ortho-carboran-2-yl)-1,2-dicyanobenzene in $n$-butanol at $140{ }^{\circ} \mathrm{C}$. Under these conditions the ortho-carborane cage undergoes partial deboronation to the nido-form resulting in water-soluble phthalocyanine 9 (Scheme 6). ${ }^{[40]}$

Water solubility of boronated phthalocyanines can be reached by change the carborane cages for the anionic dodecaborate moieties. ${ }^{[1,42]}$ However, due to higher reactivity of the closo-dodecaborate $\left[\mathrm{B}_{12} \mathrm{H}_{12}\right]^{2-}$ only the first approach can be used for synthesis of boronated phthalocyanines containing the closo-dodecaborate fragments. The first highly-boronated phthalocyanines 10-13 containing the closo-dodecaborate cages were prepared by the reaction of the aminododecaborate $\left[\mathrm{B}_{12} \mathrm{H}_{11} \mathrm{NH}_{3}\right]^{-}$with chloromethyl derivatives of phthalocyanines (Scheme 7). ${ }^{[43]}$ In vivo studies on B-16 mouse melanoma model demonstrated moderate tumor accumulation and rather high blood/tumor ratio for phthalocyanine $\mathbf{1 0}$ and no tumor accumulation for phthalocyanine 11. ${ }^{[44]}$

Boronated zinc phthalocyanine $\mathbf{1 4}$ was prepared in $71 \%$ yield by the reaction of zinc 2-(4-carboxyphenoxy) phthalocyanine with sodium mercapto-closo-dodecaborate (Scheme 8) and its photosensitizing properties at molecular and cellular level were studied. ${ }^{[45]}$

Some later the ring opening of cyclic oxonium derivative of the closo-dodecaborate anion ${ }^{[46]}$ with nucleophiles was used for synthesis of zinc phthalocyanine 15 with four boron fragments connected to the phthalocyanine core through flexible spacers (Scheme 9). The reaction of zinc phthalocyanine containing four 4-hydroxyphenoxy

Scheme 5 .

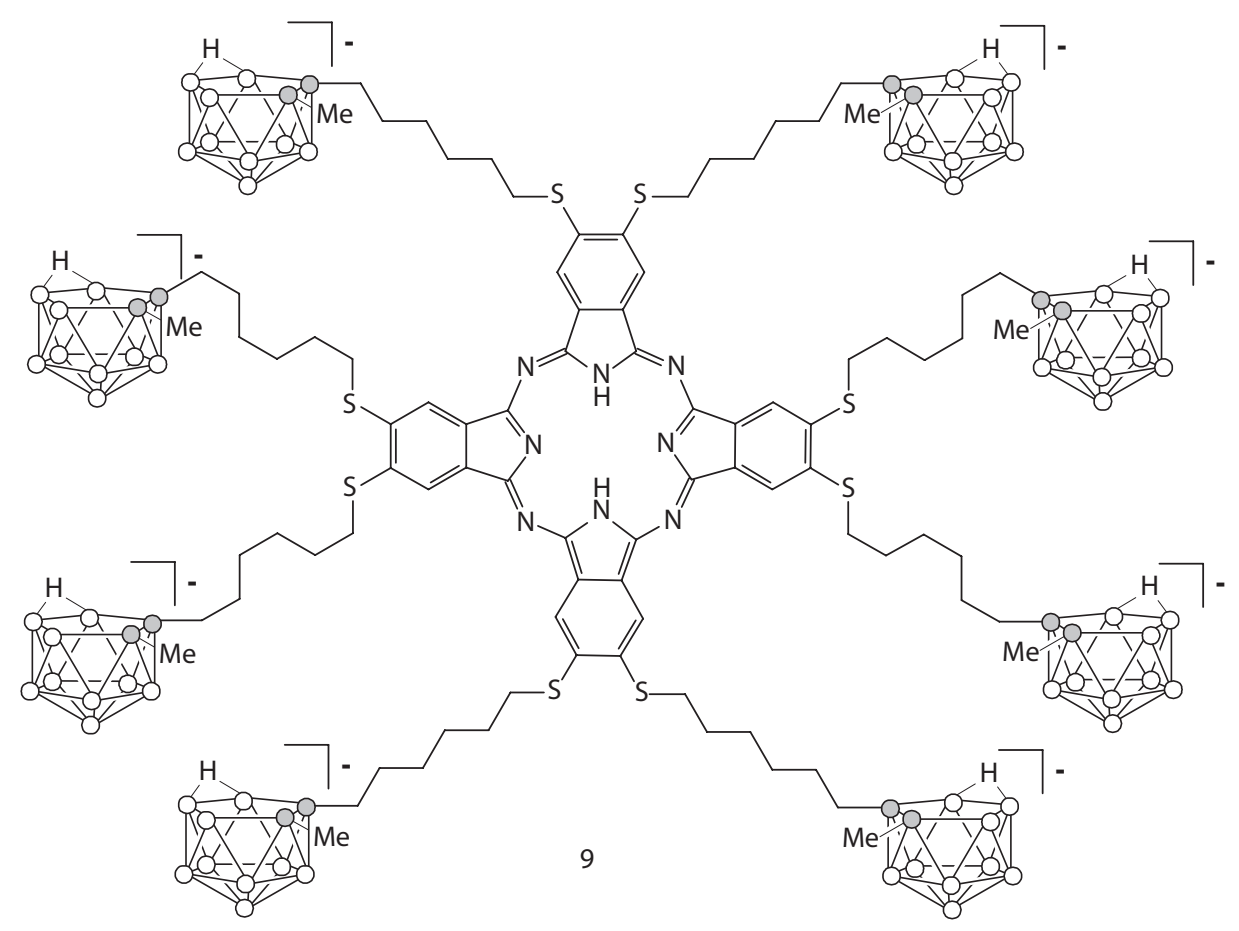

Scheme 6. 


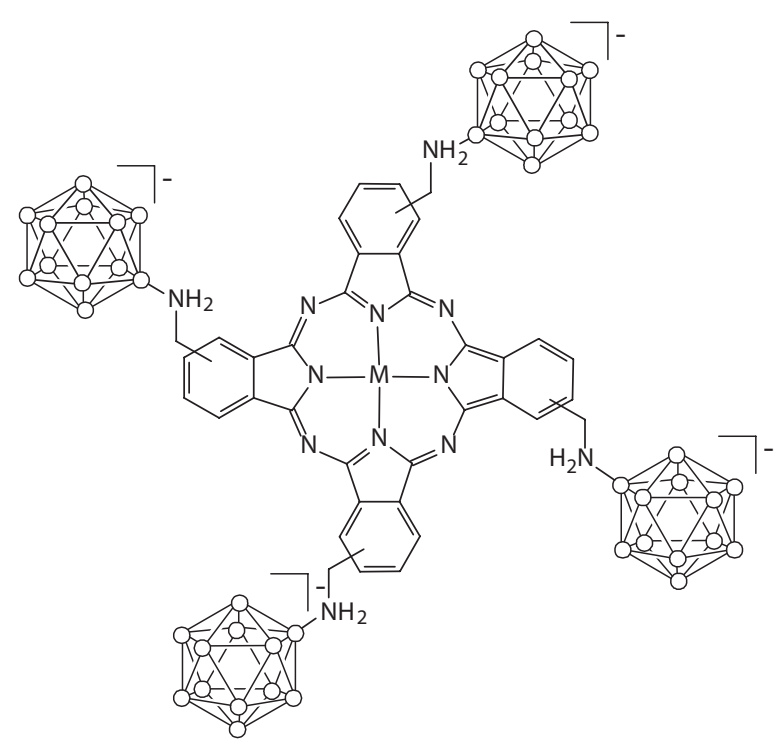

$M=\mathrm{Co}(10), \mathrm{AlOH}(11)$

\section{Scheme 7.}

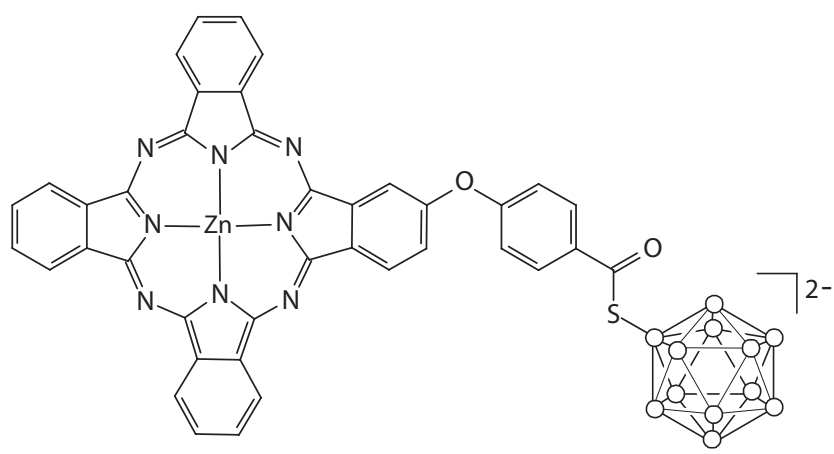

14

Scheme 8.

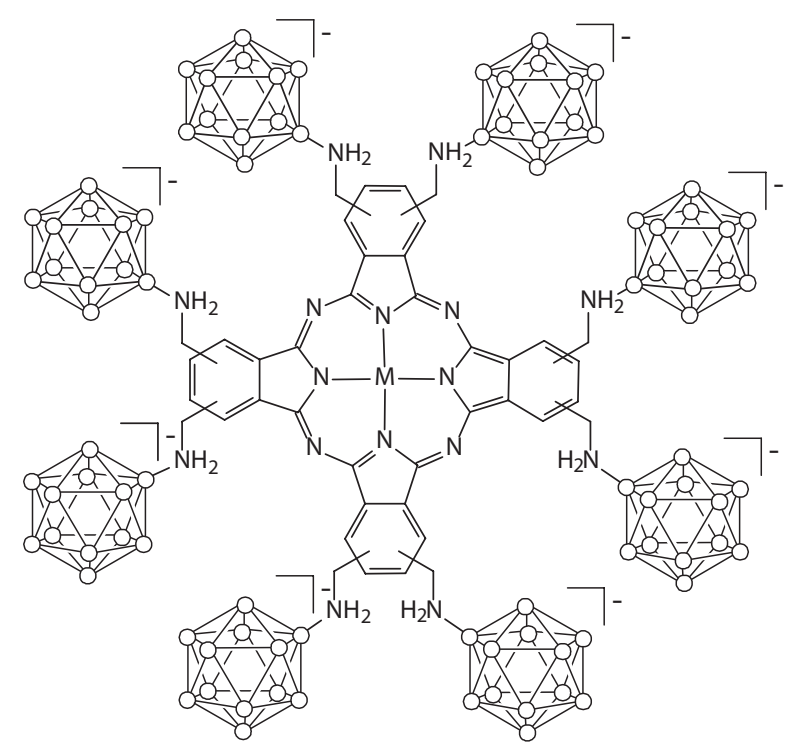

$\mathrm{M}=\mathrm{Co}(12), \mathrm{AlOH}(13)$

substituents with the 1,4-dioxane derivative of closododecaborate in the presence of $\mathrm{K}_{2} \mathrm{CO}_{3}$ gave the desired product in the $66 \%$ yield. ${ }^{[47]}$

Cobalt bis(dicarbollide) $\left[3,3^{\prime}-\mathrm{Co}\left(1,2-\mathrm{C}_{2} \mathrm{~B}_{9} \mathrm{H}_{11}\right)_{2}\right]^{-[48]}$ is another boron moiety providing water solubility of boronated phthalocyanines. A series of zinc phthalocyanines 16-19 bearing one or two boron fragments was prepared via cyclotetramerization of the corresponding cobaltacarborane substituted phthalocyanines with excess of phthalonitrile in the presence of $\mathrm{Zn}(\mathrm{OAc})_{2}$ in quinoline at $220^{\circ} \mathrm{C}$ (Schemes 10 and 11). ${ }^{[49,50]}$ The boronated phthalonitriles were synthesized using the 1,4-dioxane derivative of cobalt bis(dicarbollide). The yields of boronated phthalocyanines are low and vary from $1 \%$ for $\mathbf{1 8}$ to $15 \%$ for $\mathbf{1 6}$.

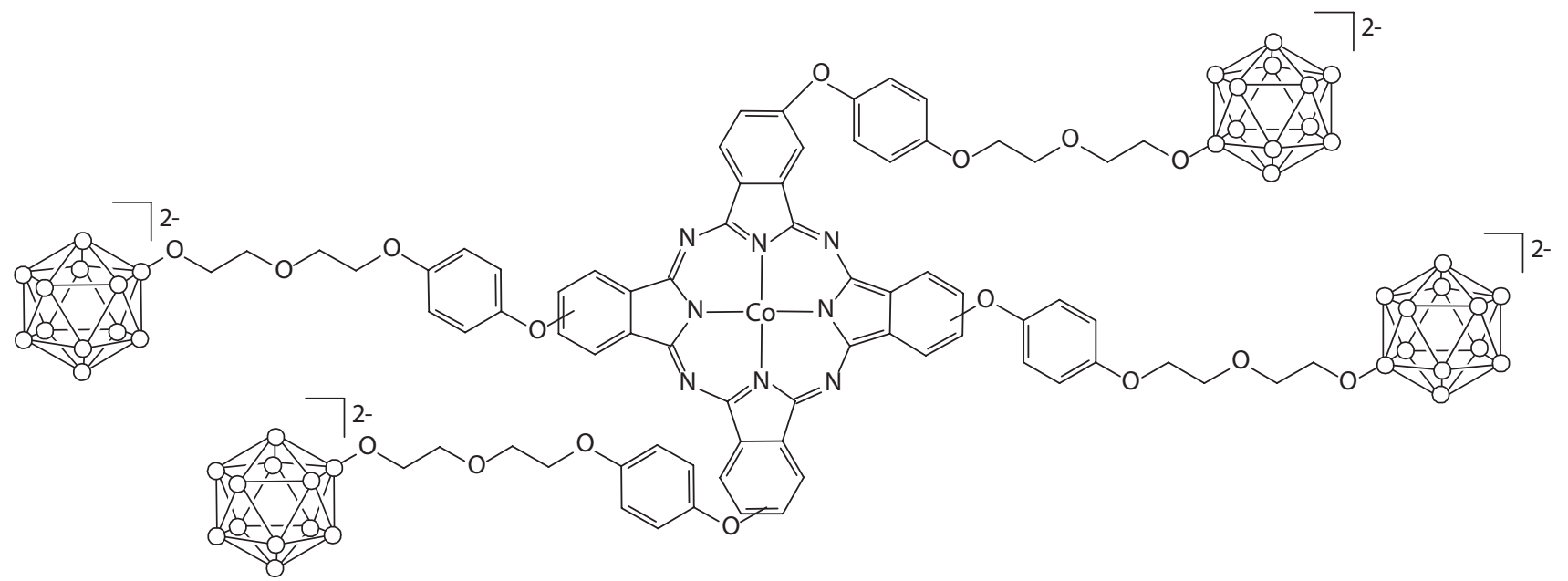




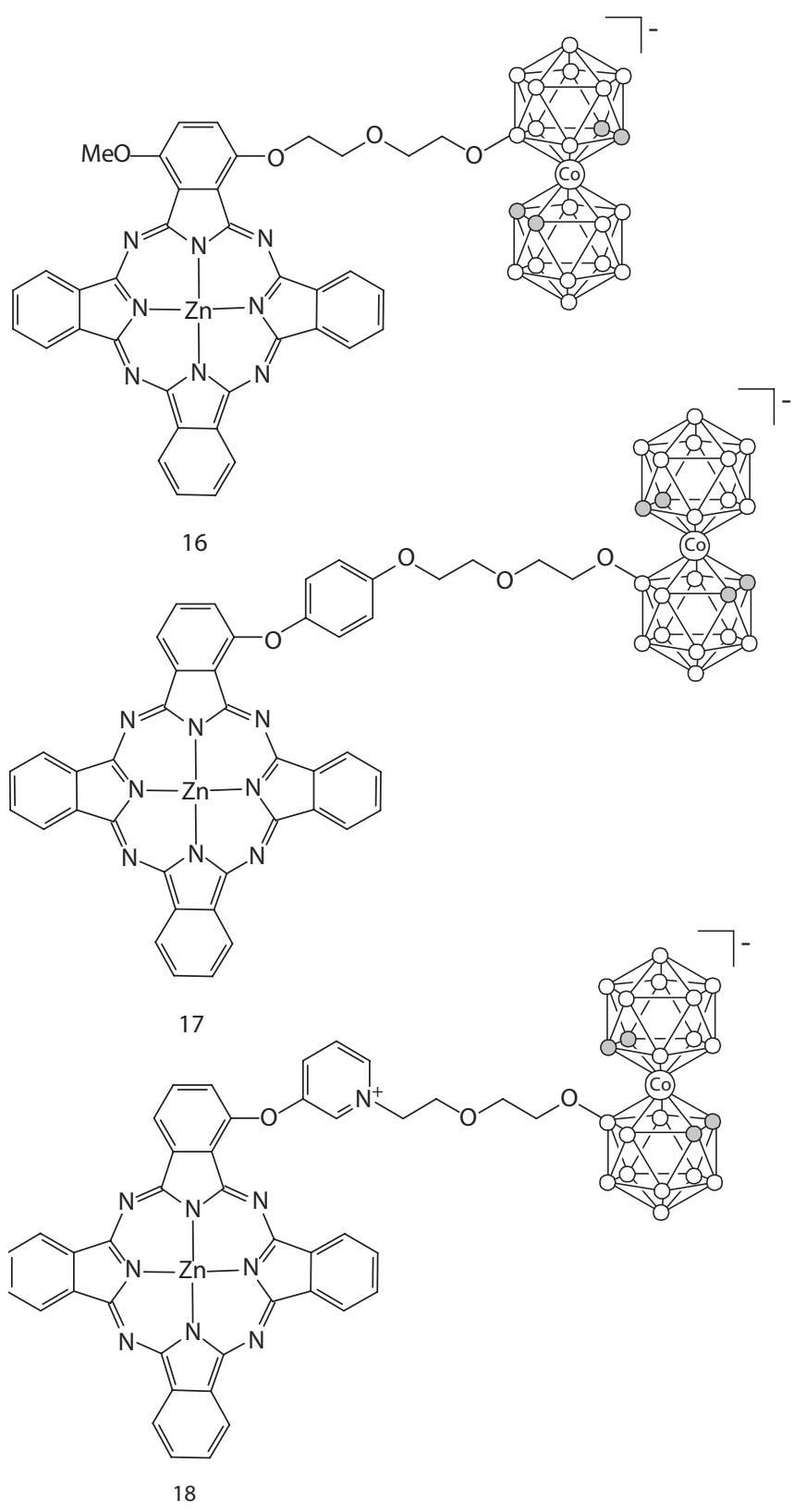

Scheme 10.
The described examples concern introduction of boron fragments on periphery of the phthalocyanine macrocycle. An alternative approach includes attachment of boron fragments to the axial positions of metal phthalocyanines. Synthesis of a series of boron-containing phthalocyanines by the reaction of silicon phthalocyanine dichloride with carborane-containing alcohols was described in patent literature. ${ }^{[51]}$

\section{Boron-Containing Porphyrazines}

Porphyrazines attract interest of researchers working in the NCT fields in the last five years when the first boroncontaining porphyrazines were synthesized. As in the case of phthalocyanines, there are two approaches to synthesis of boronated porphyrazines: 1) the first approach is based on modification of preformed macrocyclic core through the introduction of a boron moiety; 2) the second approach includes the template condensation of the corresponding boron-containing maleonitriles. The first approach was used for synthesis of the first porphyrazine containing tri-coordinated boron by reaction of magnesium octa(2hydroxyethylthio)porphyrazine with phenylboronic acid (Scheme 12). ${ }^{[52]}$

The second approach was used for synthesis of carborane-containing porphyrazines. A series of porphyrazines 21-23 containing eight carborane fragments was prepared by cyclotetramerization of the corresponding carborane-containing maleonitriles in $n$-propanol at $110^{\circ} \mathrm{C}$ in the presence of $\mathrm{Mg}(\mathrm{OPr})_{2}$ (Scheme 13). ${ }^{\left[{ }^{[3-56]}\right.}$ The synthesized highly hydrophobic porphyrazines were solubilized via loading into liposomes of different types and physicochemical properties of these lipids were studied. ${ }^{[54-57]}$

To enchance water-solubility of the prepared porphyrazines the closo-carborane groups can be converted to the nido-carborane ones by the treatment with $\mathrm{CsF}$ followed by the $\mathrm{Cs} / \mathrm{K}$ exchange to give the corresponding water-soluble boronated porphyrazines (Scheme 14). ${ }^{[53]}$

More recently synthesis of the highly boronated porphyrazine $\mathbf{2 5}$ containing sixteen carborane fragments has been reported (Scheme 15). ${ }^{[58]}$

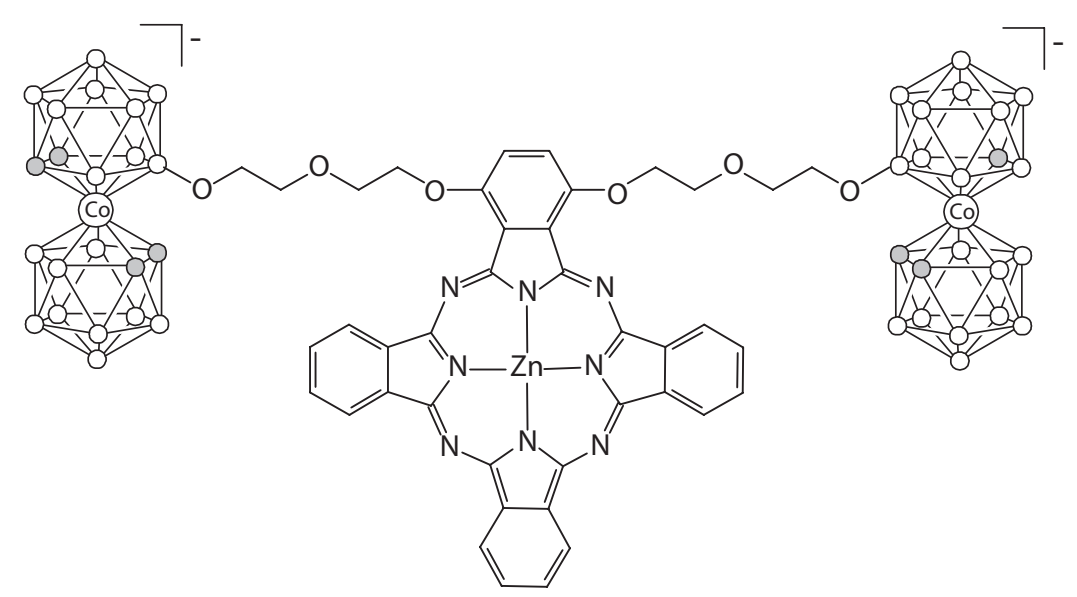

19

Scheme 11. 
Boron-Containing Phthalocyanines and Porphyrazines

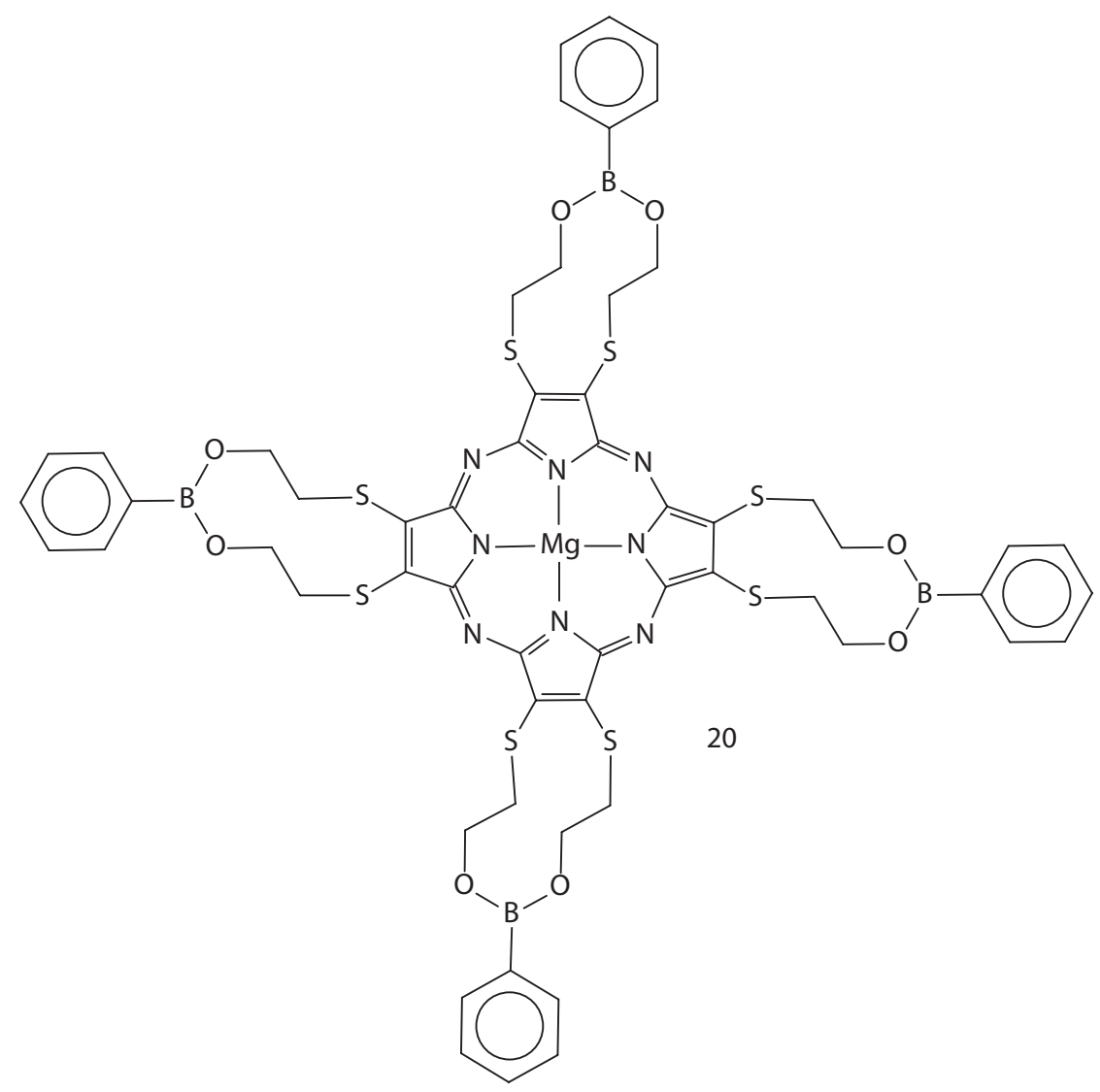

Scheme 12.

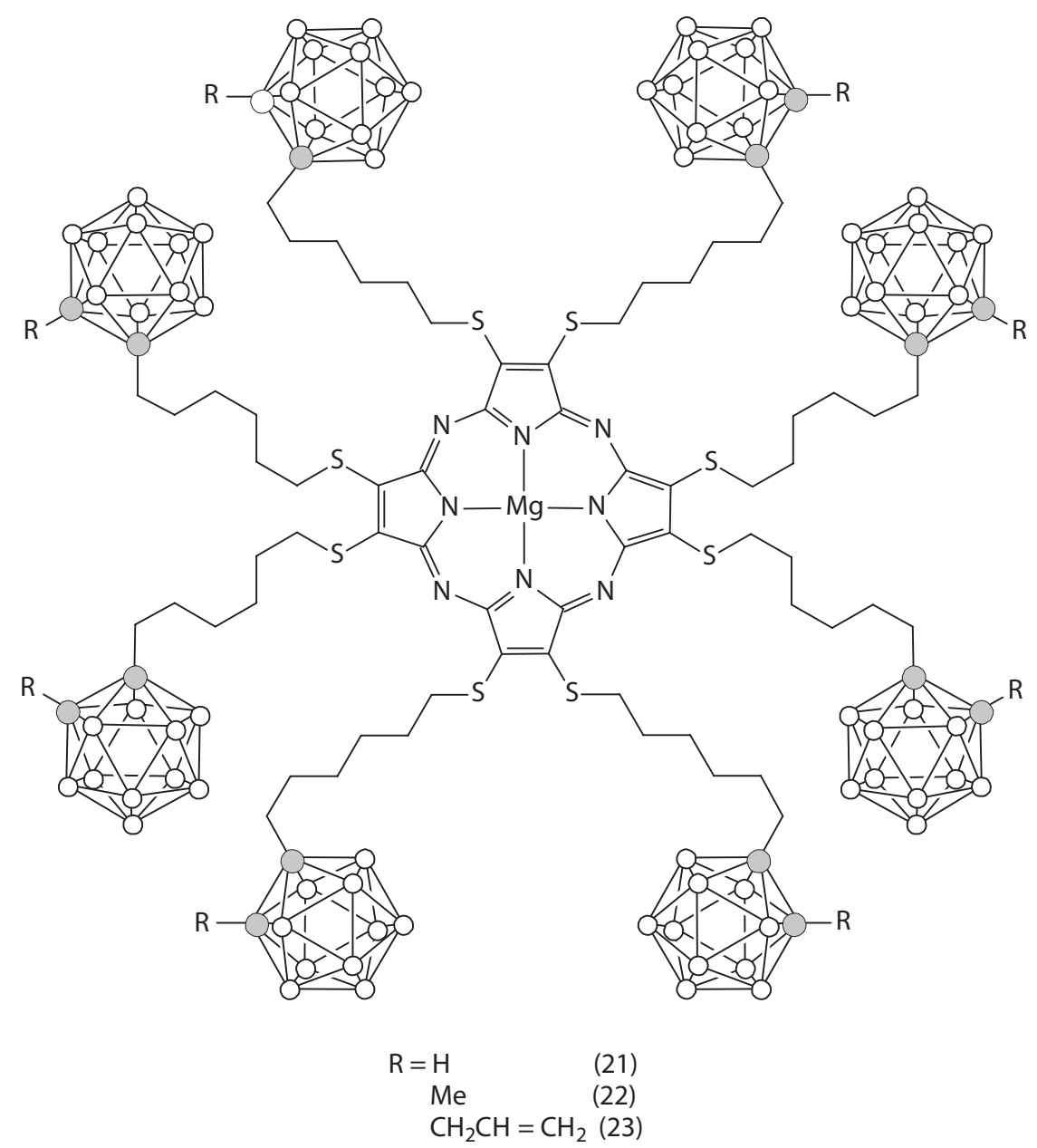

Scheme 13. 
I. B. Sivaev et al.

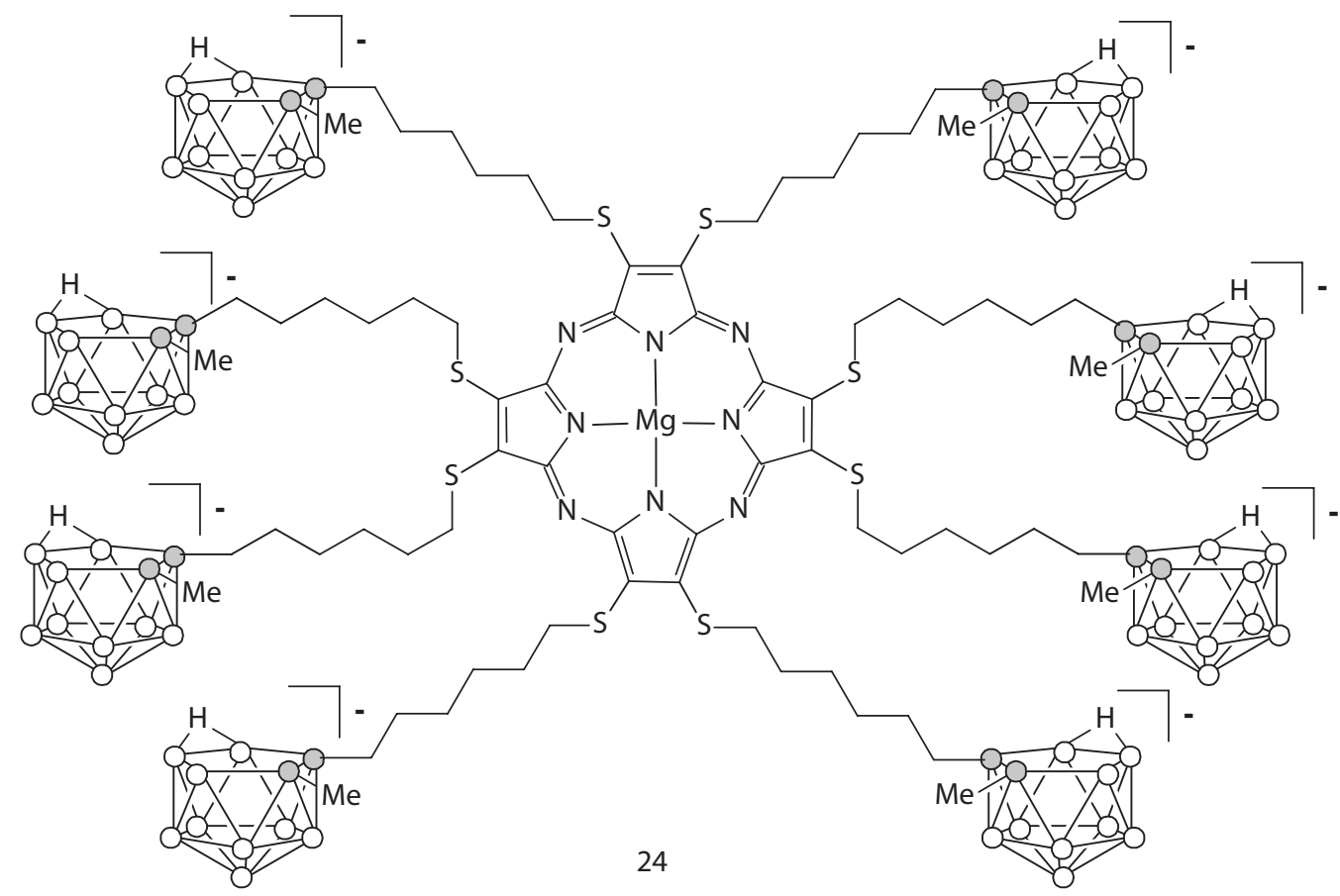

Scheme 14.
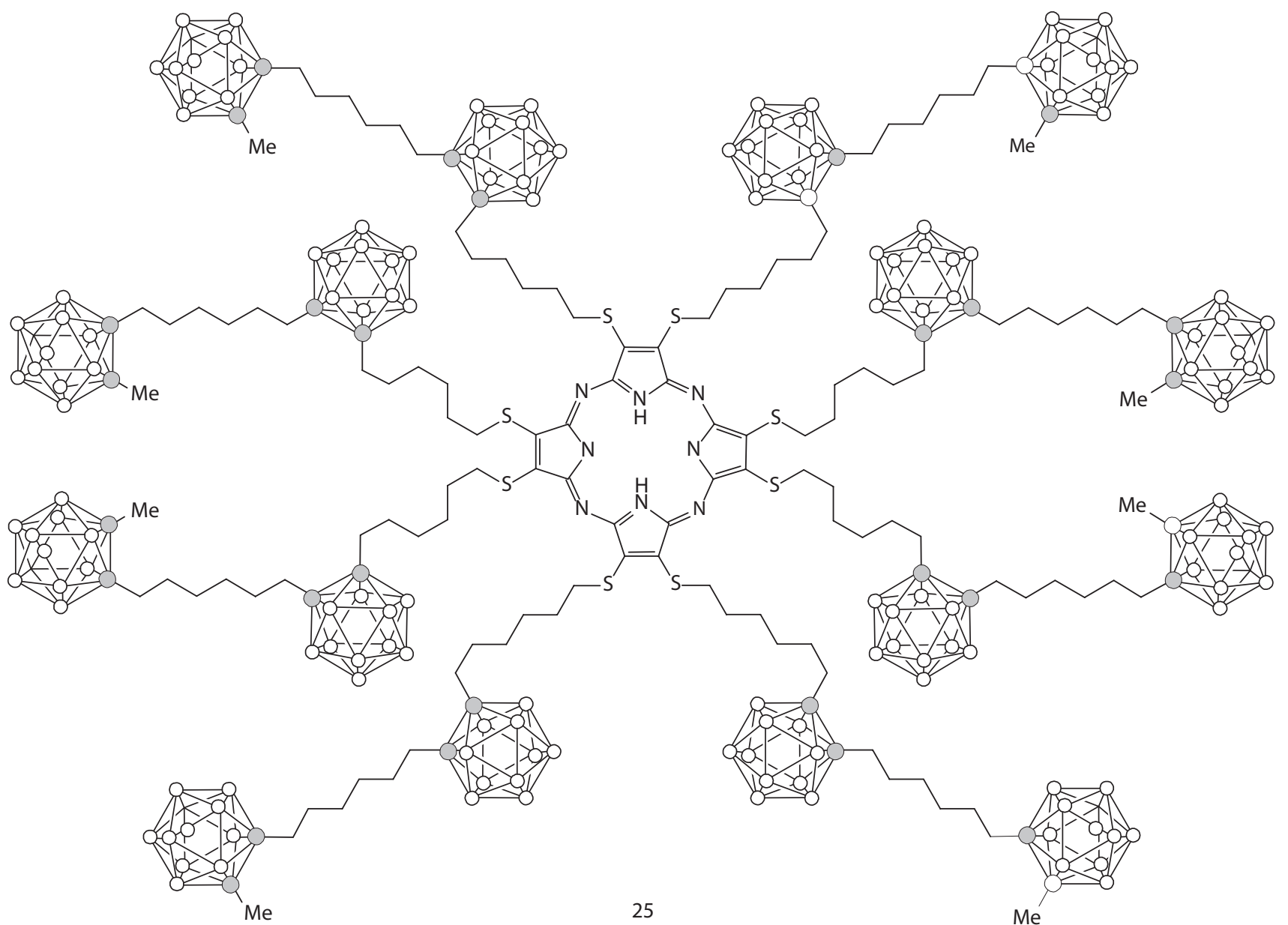

Scheme 15. 


\section{Conclusions}

Ten years ago we noted in our review ${ }^{[13]}$ that "chemistry of polyhedral boron derivatives of phthalocyanines is practically non-developed". The last decade gave a series of new examples of boronated phthalocyanines and porphyrazines bearing from one to sixteen boron fragments of various structure containing from one to eighteen boron atoms. The obtained results open new perspectives for synthesis of new BNCT agents based on tetrapyrrole macrocycles.

Acknowledgements. Financial support from the Russian Foundation for Basic Research (12-03-91375) and the Scientific and Technological Research Council of Turkey (110T833 and 211T052) is highly acknowledged.

\section{References}

1. Sharman W.M., Allen C.M., van Lier J.E. Drug Discovery Today 1999, 4, 507-517.

2. Vicente M.G.H. Curr. Med. Chem. - Anti-Cancer Agents 2001, $1,175-194$

3. MacDonald I.J., Dougherty T.J. J. Porphyrins Phthalocyanines 2001, 5, 105-129.

4. Dolmans D.E.J.G.J., Fukumura D., Jain R.K. Nature Rev. Cancer 2003, 3, 380-387.

5. Castano A.P., Demidova T.N., Hamblin M.R. Photodiagn. Photodynamic Ther. 2004, 1, 279-293.

6. Kavar B., Kaye A.H. Photodynamic Therapy. In: Current Clinical Oncology: High-Grade Gliomas: Diagnosis and Treatment (Barnett G.H., Ed.), Totawa: Humana Press, 2007. p. $461-484$.

7. Ion R.-M. The Use of Phthalocyanines and Related Complexes in Photodynamic Therapy. In: Photosensitizers in Medicine, Environment, and Security (Nyokong T., Ahsen V., Eds.), Dordrecht: Springer Science, 2012. p. 315-349.

8. Hawthorne M.F. Angew. Chem. Int. Ed. Engl. 1993, 32, 950984.

9. Soloway A.H., Tjarks W., Barnum B.A., Rong F.-G., Barth R.F., Codogni I.M., Wilson J.G. Chem. Rev. 1998, 98, 15151562.

10. Bregadze V.I., Sivaev I.B., Glazun S.A. Curr. Med. Chem. Anti-Cancer Agents 2006, 6, 75-109.

11. Barth R.F., Goderre J.A., Vicente M.G.H., Blue T.E., Miyatake S.-I. Boron Neutron Capture Therapy of Brain Tumors (Current Status and Future Prospects). In: Current Clinical Oncology: High-Grade Gliomas: Diagnosis and Treatment (Barnett G.H., Ed.), Totawa: Humana Press, 2007. p. 431-459.

12. Calabrese G., Nesnas J.J., Barbu E., Fatouros D., Tsibouklis J. Drug Discovery Today 2012, 17, 153-159.

13. Bregadze V.I., Sivaev I.B., Gabel D., Wöhrle D. J. Porphyrins Phthalocyanines 2001, 5, 767-781.

14. Evstigneeva R.P., Zaitseev A.V., Luzgina V.N., Ol'shevskaya V.A., Shtil A.A. Curr. Med. Chem. - Anti-Cancer Agents 2003, 3, 383-392.

15. Renner M.W., Miura M., Easson M.W., Vicente M.G.H. Curr. Med. Chem. - Anti-Cancer Agents 2006, 6, 145-157.

16. Ol'shevskaya V.A., Zaytsev A.V., Savchenko A.N., Shtil A.A., Cheong C.S., Kalinin V.N. Bull. Korean Chem. Soc. 2007, 28, 1910-1916.

17. Grin M.A., Brittal D.I., Tsiprovskiy A.G., Bregadze V.I., Mironov A.F. Macroheterocycles 2010, 3, 222-227.

18. Claessens C.G., Gonzalez-Rodriguez D., Torres T. Chem. Rev. 2002, 102, 835-853.
19. Kobayashi N., Kondo R., Nakajima S., Osa T. J. Am. Chem. Soc. 1990, 112, 9640-9641.

20. Musluoglu E., Gürek A., Ahsen V., Gül A., Bekaroğlu Ö. Chem. Ber. 1992, 125, 2337-2339.

21. de la Torre G., Torres T. J. Porphyrins Phthalocyanines 2002, 6, 274-284.

22. Morse G.E., Bender T.P. ACS Appl. Mater. Interfaces 2012, 4, 5055-5068.

23. Nemykin V.N., Lukyanets E.A. ARKIVOC 2010, (i), 136-208.

24. Dumoulin F., Durmuş M., Ahsen V., Nyokong T. Coord. Chem. Rev. 2010, 254, 2792-2847.

25. Ali H., van Lier J.E. Tetrahedron Lett. 2009, 50, 337-339.

26. Ali H., Ait-Mohand S., Gosselin S., van Lier J.E., Guérin B. J. Org. Chem. 2011, 76, 1887-1890.

27. Özcelik S., Keser Karaoğlan G., Gümrükcü G., Gül A. Turk. J. Chem. 2012, 36, 899-906.

28. Delman A.D., Kelly J.J., Simms B.B. J. Polym. Sci., Part A-1 1970, 8, 111-123.

29. Barnes R.L., Block W.M., Grafstein D. US 3671489, 1972.

30. Barnes R.L., Block W.M., Grafstein D. US 3730950, 1972.

31. Wynne K.J., Davison J.B. US 4132842, 1979.

32. Alam F., Bapat B.V., Soloway A.H., Barth R.F., Mafune N., Adams D.M. Strahlenther. Onkol. 1989, 165, 121-123.

33. Alam F., Soloway A.H., Bapat B.V., Barth R.F., Adams D.M. Boron Compouns for Neutron Capture Therapy. In: Clinical Aspects of Neutron Capture Therapy (Fairchild R.G., Bond V.P., Woodhead A.D., Eds), New York: Plenum Press, 1989. p.107-111.

34. Zakharkin L.I., Guseva V.V., Abramov I.G., Balagurova E.V. Russ. J. Gen. Chem. 2000, 70, 1296-1298.

35. Tsaryova O., Semioshkin A., Wöhrle D., Bregadze V.I. J. Porphyrins Phthalocyanines 2005, 9, 268-274.

36. Giuntini F., Raoul Y., Dei D., Municchi M., Chiti G., Fabris C., Colautti P., Jori G., Roncucci G. Tetrahedron Lett. 2005, 46, 2979-2982.

37. Friso E., Roncucci G., Dei D., Soncin M., Fabris C., Chiti G., Colautti P., Esposito J., De Nardo L., Rossi C.R., Nitti D., Giuntini F., Borsetto L., Jori G. Photochem. Photobiol. Sci. 2006, 5, 39-50.

38. Kahl S.B., Li J. Inorg. Chem. 1996, 35, 3878-3880.

39. Grimes R.N. Carboranes. London: Elsevier, Academic Press, 2011. $1139 \mathrm{p}$.

40. Pietrangeli D., Rosa A., Pepe A., Ricciardi G. Inorg. Chem. 2011, 50, 4680-4682.

41. Sivaev I. B., Bregadze V.I., Sjöberg S. Collect. Czech. Chem. Commun. 2002, 67, 679-727.

42. Sivaev I. B., Bregadze V. I., Kuznetsov N.T. Russ. Chem. Bull. 2002, 51, 1362-1374.

43. Zhizhin K.Yu., Malinina E.A., Goeva L.V., Chernyavsky A.S., Ivanov S.V., Lukyanets E.A., Solntsev K.A., Kuznetsov N.T. Dokl. Akad. Nauk 1997, 357, 206-208 (in Russ.).

44. Spryshkova R., Grigorieva E., Riabkova V., SpureZh., Naidenov M., Zhizhin K., Malinina E., Chernyavsky A., Luk'yanets E., Solntsev K., Kuznetsov N., Borisov G. Biodistribution Study of Novel Dodecaborate-Phthalocyanines in the B-16 Mouse Melanoma Model. In: Frontiers in Neutron Capture Therapy, Vol.2 (Hawthorne M.F., Shelly K., Wiersema R.J., Eds), New York: Kluwer Academic / Plenum Publishers, 2001. p. $1027-$ 1032.

45. Fabris C., Jori G., Giuntini F., Roncucci G. J. Photochem. Photobiol. B: Biol. 2001, 64, 1-7.

46. Semioshkin A.A., Sivaev I.B., Bregadze V.I. Dalton Trans. 2008, 977-992.

47. Semioshkin A., Tsaryova O., Zhidkova O., Bregadze V., Wöhrle D. J. Porphyrins Phthalocyanines 2006, 10, 1293-1300.

48. Sivaev I.B., Bregadze V.I. Collect. Czech. Chem. Commun. 1999, 64, 783-805. 
49. Li H., Fronczek F.R., Vicente M.G.H. Tetrahedron Lett. 2008 , 49, 4828-4830.

50. Li H., Fronczek F.R., Vicente M.G.H. J. Organomet. Chem. 2009, 694, 1607-1611.

51. Dei D., Roncucci G., Nistri D., Raoul Y., Chiti G., Municchi M., Jori G. US 7915248, 2011.

52. Başeren S.C., Özçelik S., Gül A. J. Porphyrins Phthalocyanines 2011, 15, 742-747.

53. Pietrangeli D., Riccardi G. Appl. Radiation Isotopes 2009, 67, S97-S100.

54. Ristori S., Salvati A., Martini G., Spalla O., Pietrangeli D., Rosa A., Riccardi G. J. Am. Chem. Soc. 2007, 129, 2728-2729.
55. Salvati A., Ristori S., Pietrangeli D., Oberdisse J., Calamai L., Martini G., Riccardi G. Biophys. Chem. 2007, 131, 43-51.

56. Altieri A., Balzi M., Bortolussi S., Bruschi P., Ciani L., Clerici A.M., Faraoni P., Ferrari C., Gadan M.A., Panza L., Pietrangeli D., Riccardi G., Ristori S. J. Med. Chem. 2009, 52, 78297835.

57. Salvati A., Ristori S., Oberdisse J., Spalla O., Riccardi G., Pietrangeli D., Giustini M., Martini G. J. Phys. Chem. B 2007, 111, 10357-10364.

58. Pietrangeli D., Rosa A., Riccardi G. J. Porphyrins Phthalocyanines 2011, 15, 1024-1032.

Received 05.12.2012

Accepted 18.12.2012 